\title{
Performance and Technology
}

for the 58 th Century

\author{
by Henry Bial
}

2011

This is the published version of the article, made available with the permission of the publisher. The original published version can be found at the link below.

Henry Bial. (2011). Performance and Technology for the 58 th Century. The Drama Review 55(3):134-143.

Published version: http://www.dx.doi.org/10.1162/DRAM_a_o0103

Terms of Use: http://www2.ku.edu/ scholar/docs/license.shtml 


\section{PROJECT MUSE}

\section{Jew Media: Performance and Technology for the 58th Cenntury}

TDR: The Drama Review, Volume 55, Number 3, Fall 2011 (T211), pp. 134-143 (Article)

Published by The MIT Press

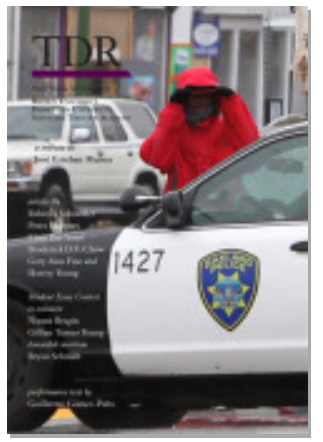

$\Rightarrow$ For additional information about this article http://muse.jhu.edu/journals/tdr/summary/v055/55.3.bial.html 


\title{
Jew Media
}

\section{Performance and Technology for the 58th Century}

\author{
Henry Bial
}

If Jews control the media, why don't we give ourselves better press?

- Jon Stewart (Neuman 2005)

When I first began researching and writing about Jewish American popular culture in the 1990s, the history of Jewish artists in the American entertainment industry was still very much a story of "changing one's name for business purposes."' Despite the preponderance of Jewish writers, directors, and actors in theatre, film, and television, there seemed to be few overtly Jewish leading characters in these media, and those characters represented a very limited part of the spectrum of Jewish experience. Other scholars such as Andrea Most (2004), David Zurawik (2003), and Vincent Brook (2003) observed the situation similarly, noting that the fear of appearing "too Jewish" seemed to be a defining factor in shaping Jewish American cultural production in the latter half of the 20th century (CE). ${ }^{2}$ This mirrored contemporaneous conversations about Jewish American identity in "real life," and the mutual authentication between onscreen Jewishness and offscreen Jewishness proved a rich terrain for scholarly investigation. ${ }^{3}$ The performance of Jewishness, I argued in Acting Fewish (2005), was double coded, carrying one set of meanings for Jews and another for non-Jews, a strategic response to a perceived need to minimize or erase "Jewish difference" when communicating with "mainstream" culture. When I lecture about this to undergraduates today, they don't know what I'm talking about.

What can it mean to minimize or erase Jewish difference when Jon Stewart appears on national television five times a week, frequently “referr[ing] to himself as 'Jewey Von Jewstein' and crack[ing] wise on Jewish noses, circumcision, anti-Semites, Jews who play baseball (a short list), Israel as 'Heebie Land' and his grandma at Passover" (Gillick and Gorilovskaya 2008)?

1. An earlier version of this essay was delivered as the keynote address for Texas A\&M University's Race and Ethnic Studies Institute's (RESI) Race, Ethnicity, and (New) Media Symposium, 1 May 2009.

2. See also Jon Stratton, Coming Out Jewish (2000); J. Hoberman and Jeffrey Shandler (2003); and numerous others.

3. On the fear of seeming "too Jewish" in everyday life, see (inter alia) Riv-Ellen Prell, Fighting to Become Americans: Jews, Gender, and the Anxiety of Assimilation (1999); Eric Goldstein, The Price of Whiteness: Jews, Race, and American Identity (2006); and David Mamet, The Wicked Son: Anti-Semitism, Self-Hatred, and the Jews (2006).

Henry Bial is Associate Professor of Theatre at the University of Kansas, where he has also served as Director of the Program in Jewish Studies. He is the author of Acting Jewish: Negotiating Ethnicity on the American Stage and Screen (University of Michigan Press, 2005), the editor of The Performance Studies Reader (Routledge, 2004, second edition 2007), and the coeditor (with Carol Martin) of Brecht Sourcebook (Routledge, 2000). His most recent book is Theater Historiography: Critical Interventions (University of Michigan Press, 2010), coedited with Scott Magelssen. hbial@ku.edu 
When self-proclaimed "Hasidic Reggae Superstar" Matisyahu has a CD on the Billboard top 100? When the coffee table book Bar Mitzvah Disco is sold at Urban Outfitters stores nationwide, and even Salt Lake City's Deseret News runs a lifestyle piece headlined, "Hipster Judaism Is Popping Up All Over" (Passy 2006). Consider that in 2005, a year that many of today's Jewish undergraduates were bar or bat mitzvahed, cable network VH1 aired a special edition of its "All Access" series titled "So Jewtastic!" described by TV Guide as "A Celebration of All Things Jewish.” As David Schneer puts it, "The assimilationist anxiety of the twentieth century is out, and cultural and sexual pride in the twenty-first is in, and this heady mixture has been very good for Jewish culture" (2007:58).

While I agree with Schneer's assessment of the current landscape of Jewish American identity, his periodization of this phenomenon reflects the temptation common to many cultural commentators writing at "the dawn of a new millennium": the urge to identify a catastrophic change between past and present. This move to categorize what has come before as radically different from what will come after is especially attractive in the age of so-called "new media." As Jeffrey Shandler writes, "So often, the first responses to new media tend toward extremes [...]" (2009:275). New technological innovations are regularly accompanied by utopian (or dystopian) prophecies, few of which turn out to be fulfilled. When the prophecy is particularly attractive ("cultural and sexual pride in the twenty-first is in"), the temptation to embrace it is even stronger, and the need for circumspection that much greater.

Hence my title: "Jew Media" - a poor pun, but one that serves two related but distinct purposes: (1) The phrase reflects the willingness of contemporary Jewish culture-makers to boldly self-identify, and to do so in a way that is at once ironic and "in your face"; (2) "Jew Media" also reflects the desire to reclaim the phrase from the anti-Semitic bloggers and hate groups who use it most often, usually as shorthand for "the public relations arm of the worldwide Jewish conspiracy."

So I write here of "Jew Media" in the spirit of queer theory, as a way of re-centering the conversation, of refusing to accept the othering that, well, others, would force upon us. Placed as it is in ironic quotation marks, the phrase "Jew Media" signals my desire for a fluid, affective understanding of identity, as well as a more nuanced relationship to mass cultural representation than that provided by a conventional cultural studies model. Jew Media requires us to assume neither a sinister Culture Industry in thrall to an equally sinister Dominant Culture, nor a community imagined on a foundation of shared victimhood. Most importantly, it offers the Jewish media consumer an opportunity to assert that "Jewish" is a meaningful category of cultural experience, while keeping a certain critical distance from the impulse to generalize (or moralize) across that category. Jew Media is characterized by irony, a time-honored strategy by which the minority negotiates its relationship to the mainstream. Some critics, myself included, have suggested that an ironic outlook toward life has itself sometimes been a coded signal of Jewishness. In a postmodern age, we might further argue that such irony in self-identification is near universal. When irony no longer reads as Jewish, it is perhaps inevitably applied to expressions of Jewish identity itself. Irony, and I use it here in the Brechtian sense, is not just about humor, it's about seeing one's struggles and the struggles of one's identity group with a certain reflexivity or critical distance. This allows "Jew Media" to repurpose anti-Jewish stereotypes as a critique of anti-Semitism, allowing us to assert Jewish pride ("If Jews control the media, why don't we give ourselves better press?") but to do so in quotation marks, as it were, to perform Jewish

4. Examples of the anti-Semitic use of the phrase "Jew Media" include blog headlines such as "Columbine: 10 Years of Jew media lies" (http://incogman.net/04/2009/columbine-10-years-of-jew-media-lies/) or "Viacom (Jew Media Control)" (http://nationalrevolution.blogspot.com/2006/04/viacom-jew-media-control.html). It is the more virulent version of the phrase "mainstream media" or "MSM" that can be found elsewhere in the blogosphere, though the term MSM has become so widely used that most contemporary uses seem to be innocent of anti-Semitic overtones. 
identity in a subjunctive mode, avoiding the pitfalls of essentialism or parochialism. Yet an examination of the history of Jewish American popular culture shows that this ironic assertion of Jewish identity represents not a catastrophic break, but a natural progression through multiple media, each of which was once "new."

My subtitle, "Performance and Technology for the 58th Century," then, is intended to address the understandable temptation to declare, "everything has changed." It plays on the now-familiar motif of utopian proclamations about "new media" and about cultural/social interaction more generally - e.g., careers for the 21 st century. In such formulations, "the 21 st century" is primarily an epistemic designator not a chronological one. It connotes technology more than time; dig into almost any document, exhibition, or website with " 21 st century" in its title and you'll find references to computers, data networks, DNA sequencing, virtual reality. The phrase "for the 58th century" similarly desig-

In either case, the theory most often deployed in media and performance studies doesn't reflect the actual

situation on the ground, which is that most subaltern groups want to see themselves as different from the dominant culture...except when they don't. nates not merely a time, but a way of thinking, one that is self-consciously Jewish. So calling this essay "Performance and Technology for the 58th Century" signals another attempt to reframe the conversation in a way that marks the Jew as the insider, and everyone else as the outsiders, or (you should excuse the expression) the goyim. Like "Jew Media," "for the 58 th Century" is a way of claiming, not without irony, that the Jewish worldview is an appropriate center or origin for my analysis. Unlike Jew Media, however, "for the 58th

Century" requires the outsider to possess insider knowledge, in this case the knowledge that in the "Common Era" it may be 11 December 2010, but according to the traditional Jewish calendar, it is the 4th of Tevet 5771 . And this deployment of insider knowledge is one way in which I signal my own Jewish identity.

Turning the tables in this way allows me to think differently about the question of new media. Instead of thinking about Web 2.0, social networking, etc., in the context of a catastrophic millennial shift, viewing developments in popular culture from the year 5771 prompts me to consider the Jew Media landscape as a natural progression of a process that can be traced back to the days of media that are no longer new: specifically film and television. Mass culture, after all, has been a critical site for the negotiation of Jewish identity in the United States since the 5680s. The explosive growth of new media has accelerated but not fundamentally changed the dynamics of that negotiation.

Even as I seek to reframe the debate in Jewish-specific terms, I also believe that Jew Media has lessons to offer all of ethnic and performance studies vis-à-vis the new media landscape. American Jews still present a problem for cultural critics: most approaches to racial and/or ethnic identity assume that a minority group (or group member) seeks either to assimilate entirely or to maintain a separatist, hyphenated identity. The desire to assimilate is usually framed as, to put it bluntly, "Bad." Assimilation is Bad because it represents the overwhelming discipline of the Dominant Culture, or because it represents self-hatred, or some combination of both. The desire to retain a separate identity is usually recognized as "Good." But this is problematic, too, as it challenges the universalist view of a society in which broader cultural norms can be shared. In either case, the theory most often deployed in media and performance studies doesn't reflect the actual situation on the ground, which is that most subaltern groups want to see themselves as different from the dominant culture...except when they don't.

Where performance intersects with technology and (new) media, identity-based analyses often fail to adequately explain the Jewish American experience. The bulk of our theory (not to mention our politics) is concerned with the notion of access. Minoritarian identities, accord- 
ing to most cultural studies scholars, are misrepresented or underrepresented in the media because minority artists do not have sufficient access to the means of cultural production. It follows, then, that to redress this problem, we need to democratize access to the media in order to democratize representation and, by extension, the culture. This is the positive promise of new media: increased opportunity to produce and distribute content seems to imply that more culturally diverse content can be produced and distributed. Hence the urgency to assure that we as a society make access to the web, to wireless networks, etc., as broad and deep as possible.

Access is important. But Jew Media shows us that access is only part of the equation. American Jews have had access to the means of mass cultural production for the better part of a century - access, even, in disproportion to their share of the general population. Yet this has not, by itself, solved the problem of Jewish identity. Access, it turns out, presents its own set of problems. Jewish American artists in the media, while certainly enjoying access at a level far from subordinate, nonetheless have tended to minimize the overt representation of Jewishness in their creative work, partly as a preemptive strategy to avoid accusations of "Jewcontrolled" media.

Jew Media, then, is always contested, always in motion, imperfectly balancing the specific ("Jewish enough") and the universal (not "too Jewish"). How then, do we get a handle on it? When I consider a performance, be it new media, old media, or what we might call the "really old media" of live theatre, I bring to bear four questions ${ }^{5}$ that structure the remainder of this essay:

1. Who's Jewish?

2. How do you know?

3. Why do you care?

4. Is it good for the Jews?

\section{Who's Jewish}

"Who's Jewish?" is a very delicate question because, by and large, the only people who care about the answer are (1) Jews; and (2) anti-Semites. ${ }^{6}$ In the new media universe, this is evidenced most prominently by the disclaimer that appears when one enters the word "Jew" into the ubiquitous search engine, Google": "If you recently used Google to search for the word 'Jew,' you may have seen results that were very disturbing. We assure you that the views expressed by the sites in your results are not in any way endorsed by Google." There follow three full paragraphs explaining, in broad terms, how the Google algorithm sorts keywords, and how "Jew" (rather than "Jewish" or other variants) is commonly used on anti-Jewish webpages. The actual results of such a Google search turn up a curious mix of sites, ranging from sites offering religious information and advice (www.jewfaw.org or www.myjewishlearning.com) to open source sites celebrating what Laurence Roth (2007) calls "Jewishness as brand identity" (www.jewtube.com or www.heebz.com) as well as the "very disturbing" hate sites (www .jewwatch.com) that document the alleged sins of the worldwide Zionist conspiracy. The keyword-oriented landscape of the World Wide Web makes such juxtapositions all but inevitable, and yet this phenomenon is not so different from the way such questions played out earlier in the 58th century. A search in a library card catalogue three or four decades ago would likely have revealed the same variation in response. Even leaving anti-Semites out of the conversation, we still have to contend with a wide range of conflicting answers, ranging from the religious

5. This is, of course, another in-joke: a reference to the four questions asked at the traditional Passover seder.

6. My Kansas colleague, Tamara Falicov, points out that there is a third, smaller population concerned with this question: what we might call philo-Semites, non-Jews who have a fascination with things Jewish.

7. A link to the disclaimer comes up first on the results list, under the heading "Offensive Search Results." 
to the cultural, from the dogmatic to the pluralistic. Often, it seems, the answer to "Who's Jewish?" is, somewhat counterintuitively, determined by the answer to our second question...

\section{How do you know?}

In the early days of the 58th century, the Jews who (in Neil Gabler's memorable phrase) "invented Hollywood" were very circumspect about the films they made and the actors they showcased. They were trying to establish the movies as "all-American" and to do so they had to de-emphasize the ethnicity of the performers (Gabler 1989). So, for example, when Jacob Julius Garfinkle (1913-1952) became an actor he decided of his own volition to change his name to Jules Garfinkle, and later to Jules Garfield (his friends called him Julie). But when he moved from New York, where he'd been a stage star, to Hollywood, the Jewish producer Jack Warner (of Warner Brothers) felt that even "Jules" was too Jewish, and suggested that he change it to James Garfield. The actor pointed out that there had been a president named James Garfield, and protested, "You wouldn't name a goddamn actor Abraham Lincoln, would you?" To which a Warner executive replied: "No, kid, we wouldn't [...] because Abe is a name most people would say is Jewish and we wouldn't want people to get the wrong idea" (Gabler 1989:301).

The studio's concern over Garfield's public image meant that he rarely got to play explicitly Jewish roles, though as Samuel J. Rosenthal (2003) has shown, this did not stop Warner Bros. from using the actor's Jewishness to market the film in the Jewish press. For example, in promoting the 1939 (5700) noir thriller They Made Me a Criminal, they ran an ad in the Los Angeles B'nai Brith Messenger with the tagline "Another Jewish Actor Rises to Stardom" (Rosenthal 2003:175). Even at the beginning of the 58th century, one answer to "How do you know?" is: through extratextual information available only to the in-group. This is a clear example of using technology (here, the then-new media of advertising) to provide supplemental information about "who's Jewish" to a self-selected Jewish audience. The Jewish press has long served this function of supporting (not to say creating) a "Jewish interpretative community" by circulating information about Jewish celebrities, and such quasi-public identifications of prominent Jews have circulated in virtually every medium.

The internet has magnified and dispersed this kind of extratextual knowledge. The question, "Is such and such famous person Jewish?" can be answered in moments from your cellphone, via any number of commercial and hobbyist websites such as JewOrNotJew.com, Heebz.com, and the ever-present Wikipedia (see: http://en.wikipedia.org/wiki/List_of_Jewish_actors). The immediacy of access to this kind of information, however, is matched by the questionable reliability of the source. This is less of a problem than it might seem, since such "crowdsourcing" of the question "Who's Jewish?" has a history that predates even the 58th century, though the "peer-to-peer networking" was conducted over coffee instead of over fiber-optic cable. More problematic is the attempt to craft a definition of Jewish that pleases all the users (consumers, producers, and "prosumers") on whom the site relies for its existence. Most address this dilemma with irony. The Heebz.com statement on "Who is a Jew?" is representative:

We've decided to sidestep this issue in order to make everyone happy. As you probably know, there are a number of ideas on who is a Jew [...] So it is our plan to indicate maternally-Jewish Jews by some kind of icon and/or tag and/or filter. For the purposes of this site we will also include individuals with only a Jewish father. We will also include individuals who have undergone an official "conversion" process through any of the major Jewish groups. Is everybody happy now? $(2010)^{9}$

8. The term "prosumer" is used by web analysts to describe the user who functions as both consumer and producer of online content.

9. Heebz.com is widely seen as the successor to the now defunct "Jewhoo" (formerly found at www.jewhoo.com), which I discuss at length in chapter 6 of Acting Jewish (2005). 
The irony and irreverence of the above statement is palpable. The tagline "Is everybody happy now?" is at once obsequious and confrontational, pandering and parodic. Roth suggests this kind of parodic opposition to "tired narratives" (like the debate about who is a Jew), "has become an important component in the cultural empowering of contemporary American Jewishness and in its marketing to both Americans and American Jews" (101).

Scholars use a variety of terms to describe the target audience for such marketing: "New Jews" (Kirshenblatt-Gimblett 2005), "alternaJews" (Roth 2007), and "Heebsters" (Cohen 2009). There seems to be general agreement

How do you know Jon Stewart is Jewish? Because he tells you, repeatedly. It's part of his act. however that this phenomenon draws on multiple influences, including queer culture, zine culture, and a concerted effort by older, more established Jewish organizations and philanthropies to support "alt-Jewishness" in an attempt to keep a new generation of American Jews connected to their Jewish identity. This ironic and irreverent "branding" of Jewishness is evident not just in the extratextual means by which we interpret cultural products, but it is increasingly central to the performance itself.

Comedian Jon Stewart is a salient example. At first glance, Stewart's brand of intellectual, self-deprecating humor might seem to be simply an update on the classic Jewish comics Sid Caesar or Woody Allen. But in fact, Stewart is doing something different-he's joking about being an insider, not an outsider. For example, on accepting the 2005 Emmy Award for The Daily Show, Stewart declared, "When I first said that I wanted us to put together a late-night comedy writing team that would only be 80 percent Ivy League-educated Jews, people thought I was crazy. They said you need 90, 95 percent. But we proved 'em wrong" (Entertainment Weekly 2005). How do you know Jon Stewart is Jewish? Because he tells you, repeatedly. It's part of his act.

\section{Why do you care?}

For the Jewish consumer of Jew Media, caring about who is Jewish and who isn't is a way to enact one's membership in the imagined community of American Jews. In other words, the answer to "Why do We Care?" is "Because by caring, we demonstrate that we belong." Lenny Bruce's infamous comic routine in which he divided the world into "Jewish" and "Goyish" (e.g., "Fruit salad is Jewish; Jello is Goyish") offers the prototype for this phenomenon, which I call "reading Jewish," a performance of identity via reading strategies. Bruce's routine has spawned a variety of imitators, including "Jewish Vs. Goyish, Web Edition," drawn from the website bangitout, which bills itself as a "Kosher Comedy Community." A few selections from their long list posted by a user named Seth:

Jewish vs. Goyish, WEB EDITION

- PC is Jewish, Mac is goyish (the commercial says it all)

- Netflix is Jewish. Blockbuster is goyish.

- eBay is a shuk, Craigslist is the bais medrash bulletin board.

- Google is searching for chometz, AskJeeves is searching for the Easter egg. (2007)

Compared to Bruce's original routine, here the in-group jokes are both more out and more in. More out - in the sense of out of the closet - because they use Yiddish and Hebrew words to emphasize Jewish difference. More in because they require more specialized knowledge to understand. A shuk, for example is a Middle Eastern market, and a bais Medrash is a Jewish study center. Note that in this case as in others, the pretense of Jewish and Goyish drops away entirely. The real purpose of the routine is to claim the world for the Jews. So when you laugh at this, and more importantly when you forward it, share it, Like it, or Digg it, you signal 
your membership in the Tribe - as clearly and unambiguously as you would by wearing your "SUPERJEW," "Moses is my homeboy," or "Yo Semite" T-shirt — which is to say, very clear, but hardly unambiguous.

Because it's not just about belonging to the group, it's about making the group the center, and the general culture the outsider looking in. Yet the claiming of the center is always already ironic. As Kirshenblatt-Gimblett writes, "[i]rreverence is one of the forms that engagement takes, and effective parody requires considerable knowledge of its target. Paradoxically, then, making Jewishness uncomfortable — creative estrangement - is what makes it "comfortable" for this group, offering it a way to say yes and no at the same time" (2005:4). Jew Media takes access, adds irony, and produces a performance that helps Jews negotiate their relationship with the broader culture.

Irony is, I'd suggest, a particularly useful tool for negotiating the new media landscape, because (at the moment at any rate), the interface encourages it. Everything on the web is at one remove from reality. Everything is in quotation marks, visible or not. To the degree that we understand belief to be an essential component of Jewish identity, we may find this problematic. We might then wonder, for all the pleasures that Jew Media offers, about the answer to our fourth question...

\section{Is it good for the Jews?}

I began this essay by noting that when I speak to college students about the erasure of Jewish identity in American popular culture, they don't really understand the circumstances under which their parents and grandparents engaged with Jew Media. The converse is also true. When I speak to older audiences (scholars and the general public) about contemporary performers such as Stewart, Sarah Silverman, or Sacha Baron Cohen (Borat), it is clear that these comics' parodic repackaging of Jewish stereotypes makes American Jews old enough to remember the Reagan administration very nervous. Such audiences are likely to have been raised to be hypervigilant about stereotypes, to prefer claims of universalism rather than separatism, to identify subtle discrimination and anti-Semitic code words ("New York media"). In short, this demographic (in which I include myself) has been raised to see every instance of Jewish representation in the mainstream through the lens of "Is it good for the Jews?"

As should be clear by now, in the 58th century it's not really possible to ask this question un-ironically. But this doesn't mean it cannot or should not be asked. "New technologies," Kirshenblatt-Gimblett reminds us, "are not only tools, but also social practices. They are also models for reimagining ways to be Jewish and to form Jewish connections" (7). To the degree that contemporary Jew Media functions to revitalize Jewish American culture, and to provide a new generation with a sense of engagement, a desire to act Jewish, then it is not perhaps too great a stretch to suggest that it can indeed be "good for the Jews." The positive promise of Jew Media, then, is the utopian prediction of technology bringing people together, preserving the best of what has come before, and encouraging radical innovation vis-à-vis what will come next. The darker side of Jew Media is partly the dystopian forecast that accompanies all new technologies: that its superficial quality and ease of use will cheapen our experience and make us stupid, that Jewish identity will be stripped of meaningful content, that the wisdom of generations and the divine presence cannot be meaningfully encountered through a screen. For those of us living in the 58th century, we also recall too painfully that new technologies offer their benefits just as freely to those who would persecute us. If you recently used Google to search for the word "few," you may have seen results that were very disturbing. These potential threats to Jewish identity - from within and without — ensure that "Is it good for the Jews?" however ironic it must inevitably be, remains an urgent and necessary question. 


\section{Why is this night different from all other nights?}

The four questions at Passover are actually framed by a meta-question — an overarching idea. Before we ask why we eat matzoh, why dip the greens, etc., we ask, "Why is this night different from all other nights?" And the meta-answer is, "You shall tell your child on that day, this is because of what God did for me when I was a slave in Israel" - not some remote person, but for me, because we are one people. We are timeless, not in the sense of unchanging, but in the sense of continually embodying and reenacting our own narrative. It is the questions, not the answers, that define the community.

To put it another way, the commitment to inquiry and debate about how Jewishness is defined is, arguably, a defining factor of Jewish identity. French Rabbi and philosopher MarcAlain Ouaknin writes:

The Zohar says: "When a man by means of inquiry and reflection has reached the utmost limit of knowledge, he stops at Mab (the what?), as if to say, what have you understood?" [...] The "What have you understood?" is not a negative result of the cognitive procedure: the "what?" adorned with its question mark is the positive result that should be achieved. We can say that "the essence of reason consists not in securing for man $(M a b)$ a foundation and powers, but in calling him into question (Mab?)." ([1986] 1995:236)

Hank Lazer (2009) draws on Ouaknin's study of Talmudic hermeneutics, The Burnt Book, to suggest that the contemporary online world shares some formal similarities with this central text of Jewish thought. In Lazer's reading, the Talmud, with its multicolumn layout juxtaposing scripture with commentary with commentary on commentary, and so on, anticipates new media creations such as social network sites; it is a collective document that grows through individually actualized readings and writings. He writes (quoting Ouaknin):

One might quite rightly talk about such textuality as an ongoing accretion, the page as a kind of palimpsest, or a perpetual additive thinking or conversing or interpreting. So that we might say that "the creation of meaning is a creation-production of time" (p. 171).

Or we might acknowledge the pre-digital yet proleptic nature of that 1523 page and say it is an early example of Facebook or MySpace or an early blog or a Wikipedia entry. (Lazer 2009:75)

The phrase "people of the Book" may seem to imply a kind of fixed, timeless identity forma-

The commitment to inquiry and debate about how Jewishness is defined is, arguably, a defining factor of Jewish identity. tion. "As Israel has kept the Torah," goes the saying, "so has the Torah kept Israel" (Fackenheim [1982] 1994:328). ${ }^{10}$ But as Lazer points out, "The Book" is not single but multiple; not frozen in time, but continually being written.

It is precisely because of this that the meta-question is also, in a sense, a trick question. This night is not different from all other nights. The Passover seder does enact a catastrophic break from the past (the Exodus from Egypt), but it is a re-enactment. It is as much about looking backwards as it is about looking forwards, as much about continuity as it is about change. So too, with Jew Media. As Shandler writes, "True to the multiple meanings of the term media, new technologies effect their most significant innovations in religious life by establishing new connections and thereby creating new in-between loci. These are situated not on the frontier, looking into a limitless void [...] but rather at some new interstice, and so they look back and forth

10. Fackenheim, a Reform rabbi, cites this quote as a pre-existing aphorism. 
among known options" (2009:281). In the world of Jew Media, every night poses its four questions. Reminding ourselves that we are not only Standing on the Dawn of a New Millennium but also heading into the final third of the 58th Century is a good way to keep our perspective.

\section{References}

bangitout.com. 2007. "Jewish Vs. Goyish, Web Edition.” Comment posted by Seth, 8 May. www.bangitout .com/articles/viewarticle.php?a=1878 (15 September 2010).

Bial, Henry. 2005. Acting Jewish: Negotiating Ethnicity on the American Stage and Screen. Ann Arbor: University of Michigan Press.

Brook, Vincent. 2003. Something Ain't Kosher Here: The Rise of the "Fewish" Sitcom. New Brunswick: Rutgers University Press.

Cohen, Judah. 2009. “Hip-hop Judaica: The Politics of Representin' Heebster Heritage.” Popular Music 28, $1: 1-18$.

Entertainment Weekly. 2005. "Sound Bites: Special Emmy Edition.” 23 September. www.ew.com/ew/article /0,,1107927,00.html (30 December 2010).

Fackenheim, Emil L. [1982] 1994. To Mend the World: Foundations of Future Fewish Thought. Bloomington: Indiana University Press.

Gabler, Neal. 1989. An Empire of Their Own: How the fews Invented Hollywood. New York: Anchor Books.

Gillick, Jeremy, and Nonna Gorilovskaya. 2008. "Meet Jonathan Stuart Leibowitz (aka) Jon Stewart: The wildly zeitgeisty Daily Show host.” Momentmag.com, (November/December 2008). www.momentmag .com/Exclusive/2008/2008-11/200811-JonStewart.html (13 September 2010).

Goldstein, Eric. 2006. The Price of Whiteness: Fews, Race, and American Identity. Princeton: Princeton University Press.

Heebz.com. 2010. "Famous Jews: About.” www.heebz.com/about. (15 September).

Hoberman, J., and Jeffrey Shandler. 2003. Entertaining America: Fews, Movies and Broadcasting. Princeton: Princeton University Press.

Kirshenblatt-Gimblett, Barbara. 2005. "The 'New Jews': Reflections on Emerging Cultural Practices.” Paper presented at the "Re-thinking Jewish Communities and Networks in an Age of Looser Connections" conference. Wurzweiler School of Social Work, Yeshiva University and Institute for Advanced Studies, Hebrew University, 6-7 December 2005. New York City. www.nyu.edu/classes/bkg /web/yeshiva.pdf (15 January 2010).

Lazer, Hank. 2009. "Is There a Distinctive Jewish Poetics? Several? Many?: Is There Any Question?" Shofar: An Interdisciplinary fournal of Jewish Studies 27, 3 (Spring):72-90.

Mamet, David. 2006. The Wicked Son: Anti-Semitism, Self-Hatred, and the fews. New York: Schocken Books.

Most, Andrea. 2004. Making Americans: Fews and the Broadway Musical. Cambridge, MA: Harvard University Press.

Neuman, Joshua. 2005. "History of the World, Part 2: Jewish Conspiracy Theory: The Satire.” Slate, 21 October. www.slate.com/id/2128525/ (10 September 2010).

Ouaknin, Marc-Alain. [1986] 1995. The Burnt Book: Reading the Talmud. Trans. Llewellyn Brown. Princeton: Princeton University Press.

Passy, Charles. 2006. "Hipster Judaism Is Popping Up All Over.” Deseret News, 25 March. www.deseretnews .com/article/635194220/Hipster-Judaism-is-popping-up-all-over.html (14 September 2010).

Prell, Riv-Ellen. 1999. Fighting to Become Americans: Fews, Gender, and the Anxiety of Assimilation. Boston: Beacon Press.

Rosenthal, Samuel J. 2003. "John Garfield.” In Entertaining America: Fews, Movies and Broadcasting, eds. J. Hoberman and Jeffrey Shandler, 173-75. Princeton: Princeton University Press.

Roth, Laurence. 2007. “Oppositional Culture and the 'New Jew' Brand: From Plotz to Heeb to Lost Tribe.” Shofar: An Interdisciplinary fournal of Jewish Studies 25, 4 (Summer):99-123. 
Schneer, David. 2007. "Queer Is the New Pink: How Queer Jews Moved to the Forefront of Jewish Culture." Fournal of Men, Masculinities and Spirituality 1, 1 (January):55-64.

Shandler, Jeffrey. 2006. "Queer Yiddishkeit: Practice and Theory.” Shofar: An Interdisciplinary Fournal of fewish Studies 25, 1 (Fall):90-113.

Shandler, Jeffrey. 2009. Fews, God, and Videotape: Religion and Media in America. New York: New York University Press.

Stratton, Jon. 2003. Coming Out Jewish. London: Routledge.

Zurawik, David. 2003. The fews of Prime Time. Hanover, NH: Brandeis University Press and University Press of New England. 